\title{
Sivistyksen puolustus: miksi akateemista elämää tarvitaan? Sari Kivistö \& Sami Pihlström
}

Sari Kivistön ja Sami Pihlströmin teos Sivistyksen puolustus: Miksi akateemista elämää tarvitaan? (Gaudeamus 2018) käsittelee kriittisesti Suomen yliopistolaitoksen kehitystä ja nykytilaa. Painopiste on humanistisissa tieteissä, mutta teos käsittelee yleisemminkin sivistyksen ja akateemisen elämänmuodon merkitystä yliopistossa.

Yksi tapa kiteyttää Kivistön ja Pihlströmin sanoma käsitteen akateeminen elämä ympärille voisi olla seuraava:

- akateeminen elämä tarvitsee aikansa ja tilansa, joita yksipuolisesti välittömiä hyötyjä etsivä instrumentaalisuus ei saisi syödä

- akateemisen elämän olemassaolo on siunaukseksi koko yhteiskunnalle

- suomalaisen nyky-yliopiston erinäiset vieraannuttavat käytännöt uhkaavat akateemista elämää.

Kirjassa on omistettu kokonainen luku kirjastolle akateemisen elämänmuodon ytimenä ja symbolina.

Tarkastelen Kivistön ja Pihlströmin teosta parin oman julkaisuni kautta (erit. Suominen 2016 ja 2017a), sillä ne tulevat temaattisesti lähelle teosta. Tällä tavoin kirja-arvio on samalla jatkopuheenvuoro käsiteltävästä asiasta. Tarkastelutavan hintana on, että osa tekijöiden kiinnostavista pohdinnoista jää vähemmälle huomiolle.

\section{Ajatus ja (vai) julistus}

Humanistis-sivistyksellisiä kannanottoja ja yleistä puhetta yliopiston puolesta vaivaa usein tiet- ty äänenpaino, jota parhaiten kuvaa ison alkukirjaimen käyttö: Tiede, Tieto, Tutkimus, Tutkija - ja verbinä Tehdä Tutkimusta - ja sitten joko retoriikan tai aivan asiankin vuoksi tarvittaessa vielä Sivistys. Puhutaan myös Tieteestä vastavoimana totuuden jälkeiselle ajalle ja vaihtoehtoisille totuuksille - ikään kuin olisi vain yksi ja kaiken kattava Tiede kaikille yhteisine perusteineen. Jotain analyyttisempää tarvittaisiin.

Ylevien sanojen ongelmaa on myös Kivistön ja Pihlströmin teoksessa, jossa yhdistyy humanistisen paatoksen sävyttämää vakuuttelua ja väliin sitten käsitteellisiä jännitteitä esiin tuovaa analyyttisempaa erittelyä. Toisaalta teoksesta löytyy myös mielenkiintoisesti jännitteisiä teemoja, joilla on myös - tosin hieman huomaamattomasti - tematisoivaa merkitystä kautta kirjan. Tekijät esittävät (s. 33-) populismin vastavoimaksi avointa elitismiä, mutta sivistysprojekti on toisaalta "tuotava [...] kaikkien ulottuville" (s. 36). Elitismi ja varsinkin avoin elitismi saattavat tuntua melkeinpä provokaatiolta, mutta nähdäkseni kirjoittajien näkökannalle on olemassa erittäin hyviä perusteita.

Tietoon liittyvistä ja liittyneistä metaforista rakentuu mm. vertikaalisuuden ja horisontaalisuuden ja siihen liittyen syvyyden ja laajuuden jännitteiset vaihtoehdot. Karkeistaen voi sanoa, että yliopisto- ja tiedepolitiikan nykymeno painottaa horisontaalisuutta ja laajuutta, kun taas sivistysprojektille jotenkin paremmin luonteenomaista olisivat vertikaalisuus ja syvyys. Toisaalta itsessään ehkä hieman epämääräinenkin sy- 
vyys saa sisältöä laajuuden ja horisontaalisuuden vastakohtana ja myös, kun siihen liittyy myös sisäisyyden jännite ulkoisten paineiden ja sovellettavan tiedon vaatimusten kanssa (ks. s. 52-53). Syväksi voitaneen käsittää myös se, minkä tuottaa pitkäjänteinen jonkin asian parissa työskentely (s. 120-). Tämän hieman triviaalinkin toteamuksen kautta syvyyden attribuutti kytkeytyisi melko suoraan tekijöiden kiinnostaviin ja monipuolisiin pohdintoihin siitä, mikä on monografian merkitys - ja miksi niitä tarvitaan nykyisinkin johtuen juuri tutkimuskysymysten spesifioitumisesta, millä toisaalla pyritään osoittamaan monografian vanhentuneisuutta (ks. s. 87).

Esimerkkinä historiallisten taustojen hahmottelusta teoksessa saamme lukea, miten jo 1600-luvulla nuhjuista kirjastoon linnoittautuvaa oppinutta arvosteltiin, kun oppineen ihanteeksi oli tulossa salonkien sujuva seuramies (s. 102 ja 190-). Ehkä pienenä höysteenä tässä voisi mainita $\mathrm{Pa}$ riisissa, Tubœufin palatsin siipirakennuksessa sijainneen, Gabriel Naudén hoitaman kardinaali ja ministeri Jules Mazarinin kuuluisan ja yleisölle avoimen kirjaston. Vielä 1640-luvulla kirjasto ymmärrettiin varustaa sivuovella, josta arka ja vetäytyvä (timid and retiring) tutkijakin saattoi tulla sisään väistäen palatsin pääpihan (ks. esim. Clarke 1970, 1). Metaforisesti sellainen sivuovi voisi nytkin olla kovasti tarpeellinen, että voitaisiin säilyttää edes jotain nykysuomalaisessa yliopistossa niin ahdistetusta elävästä hengestä.

Kivistön ja Pihlström mainitsevat kirjansa kantavan sivistyksen käsitteen juuriksi Immanuel Kantin käsityksen valistuksesta itse aiheutetun alaikäisyyden ylittämisenä ja antiikin paideia-käsitteen. Sivistystä itsessään he luonnehtivat Georg-Henrik von Wrightin Paideia-esseen ilmaisulla "ihmistä kehitetään ihmisenä". (s. 31-32). Heillä on huoli sivistyksen itseisarvoisuuden katoamisesta (s. 10).

Itseisarvoksi voimme tietenkin käsittää sen, mitä on syytä tavoitella silloinkin, kun siitä ei seuraa mitään muuta arvokasta - tai jopa, kun sen edistäminen on vahingollista jonkin toisen tavoi- teltavan asian kannalta. Näin käsittäen itseisarvo voi samalla olla myös välinearvo. Toisaalta, kun tekijät (s. 156) kirjoittavat, että "[t]iedon itseisarvoisuus ei tietenkään kiistä tiedon välineellistä arvoa”, on tämä epäilemättä yhtä lailla perusteltu kuin jännitteitä tuottavakin huomautus, jos ajatellaan vaikkapa tiede- ja yliopistopolitiikkaa. Omasta puolestani joka tapauksessa näen koko (itseis)arvopuheen ongelmalliseksi mm. siksi, että se usein jää vain juhlapuheen omaiseksi julistukseksi ja toisaalta argumentoitaessa pelkästään käsittein väline- ja itseisarvo on hyvin vaikea välttää vetoamista välineellisiin hyötyihin, kun halutaan osoittaa jonkin asian itseisarvoisuuta. Myös Kivistö ja Pihlström ylittävät itsearvoisuuspuheen huomautuksellaan kirjallisuuden merkityksestä, joka on "paljon perustavampi - transendentaalinen, ei vain kontingentti - kuin välineellistävissä käsityksissä sen arvosta [...] oletetaan” (s. 179). Omasta puolestani pidän parempana haastaa kaiken kattavasti instrumentalistista ajattelua käsitteellä konstitutiivinen. (Suominen 2016, 33-, ja 2017b.)

Kivistön ja Pihlströmin mukaan nykyajassa pitää korostaa sivistysprojektin yksilöllisyyttä (s. 32). Tämä on suhteessa myös myöhemmin korostettuun yksilöllisyyden merkitykseen humanistisessa tutkimuksessa ja vaikkapa kirjoittamisessa. Nähdäkseni meidän ajassamme ehkä erityisen terveellisesti korostettava sivistyksen puoli olisi hieman toinen. Oleellista olisi yksilön kasvaminen - tai osana yleisempää yhteiskunnalliskulttuurista konstituutiota hänen itsensä konstituoituminen - suvereenina moraalisena subjektina, joka toisiakin kuulemaan valmiina ylittää pelkän pakkomielteisesti yksilöllisen halunvallan (ehkä mieluummin kuin 'mielivaltainen' hieman toisen suuntaisine konnotaatioineen; saks. Wilkür, engl. willfulnes), näin tavoittaen universaalisuutta hegeliläis-gadamerilaisen sivistyksen mielessä (Neuhouser 2000, 248-251 ja Gadamer 1992, 17-18). Näitäkin painotuksia Kivistöltä ja Pihlströmiltä toki löytyy.

Toistuva teema teoksessa on asioihin liittyvä 
eksistentiaalinen ulottuvuus. Kirjoittajat pohtivat akateemisen elämän mahdollisuuksien ehtoja - kantilaisessa mielessä kuten he korostavat. He eivät tarkoita ainakaan ensisijaisesti ulkoisia tekijöitä, vaan paremminkin sitä, "miten meille voi käydä" tai " millaisiksi me itse saatamme muuttua tässä ajassa ja näissä olosuhteissa”. (s. 101). Akateemisen elämänmuodon ehdot eivät toteudu, jos ei enää ole sellaisia eläjiä, jotka voisivat ja osaisivat sitä elää. Ulkoiset ehdot saattavat osaltaan konstituoida vieraannuttavasti meidän niin yksilöllistä kuin yhteistäkin elämäämme.

\section{Eksistentiaalinen välttämättömyys sivistyksen ideaalin perustana ja vaalimisen rationaliteetti}

Ankaran käsitteellisesti ja myös analyyttisesti voimme lähestyä humanististen tieteiden rationaliteettia hermeneuttisesta filosofiasta ja selkeimmillään ehkä Hans-Georg Gadamerin (1992, 245-) "tradition ja auktoriteetin rehabilitaation" sekä meidän "historialle kuulumisemme" (vs. historian meille kuulumisen) tematiikasta lähtien. Havainnollinen on myös Gadamerin (emt., 419420) oma pohdinta kuulosta hermeneutiikan varsinaisena aistina. Voimme katsoa toisaalle, mutta emme voi kuunnella toisaalle. Itse olen tiivistänyt Gadamerin ajatusta lausahdukseen "kaikki me aloitamme vuorollamme, ja aina aloitamme jotain, joka jo on” (Suominen 2016, 132). Tässä hyvin voimme puhua jo eksistentiaalisesta välttämättömyydestä ja ehdosta.

Sivistyksenkin kasvatuksellisena ja kulttuurisena ideaalina - eikä siis enää suoranaisena eksistentiaalisena välttämättömyytenä - voimme hyvin käsittää ideaaliksi, jolla on kuitenkin perustuksensa tuossa välttämättömyydessä. Näin kyse enää ole pelkästä itseisarvoisuuden julistuksesta. Sivistyksellinen toiminta olisi sen vaalimista ja kultivoimista, mikä jo itsessäänkin väistämättä tapahtuu.

Oleellista Gadamerilla (1992, 264) on, että sitä, mitä traditio meille antaa, ei pidä katsella elämän ilmiönä. Sitä pitää kuulla, kuunnella ja ot- taa todesta ja huomionarvoisena puheenvuorona se, mitä vaikkapa jokin teksti on sanomassa siitä, mikä on totta, mikä oikein jne. juuri käsillä olevassa asiassa. Pitää kysyä, mitä teksti kertoo itse tuosta asiasta, ei niinkään, mitä se kertoisi kirjoittajasta tai ehkä hänen ajastaan.

Gadamerilla (emt., 432) tradition kuulemisesta, kuuntelusta ja sen kanssa käytävästä keskustelusta ja sitä kautta myös sen omaksumisesta (appropriaatiosta) rakentuu tai konstituoituu kieli laajassa merkityksessä olemisena, jota ylimalkaan voimme ymmärtää, ja myös meidän kunkin osallisuus siinä kielessä. Gadamerin pohjalta voisimme ajatella, että sivistyksen problematiikka on väistämättä ikään kuin läsnä myös muissa kuin humanistisissa tieteissä, vaikkakaan ei välttämättä niiden keskiössä. Tämä voisi olla kommentti siihen, kun tekijöillä jää jossain määrin auki, puhuvatko he juuri humanistisista tieteistä vaiko tieteistä yleensä.

Kriittisen (usein nimenomaan itsekriittisen ja esimerkiksi ideologiakriittisen) ajattelun mahdollisuutta ajatellen ja Paul Ricoeurin (esim. 1981) hengessä täsmentäisin kuitenkin, että traditiota on syytä myös analysoida, millä voi tietenkin olla merkitystä myös mietittäessä nimenomaan humanistisia tieteitä. Kivistöllä ja Pihlströmillä onkin kautta linjan esillä kriittisen ajattelun ylläpitäminen asiana, jota on syytä tavoitella. Gadamerilla (1992, 274-) itselläänkin esiintyy kritiikin momenttina - tosin nähdäkseni vain rajallisesti sen eri ulottuvuuksia tavoittaen - soveltaminen kuulijan tai tulkitsijan tilanteeseen (subtilitas applicandi).

Kritiikki on viime kädessä vain toinen ja itse asiassa tradition omaksumiselle alisteinen puoli asiaa ja tradition omaksuminen jo ilman kritiikkiäkin voi olla aktiivinen osa sivistyksen ideaalin mukaista elämää ja tutkimusta. Kritiikki itsessäänkin voi edellyttää myös tradition tai traditioiden omaksumista. Vähänkin vaikuttavampi kritiikki jo itsessään tarvitsee omat kritiikin traditionsa ja radikaaleinkin, jopa vallankumoukseen johtava kritiikki - useammin kuin ehkä ajattelemme- 
kaan - tapahtuu keskusteluna traditioina elävän yhteisen rationalisuuden puitteissa, mahdollisesti (ja toivottavasti) aivan vilpittömästi tuon tradition antamiin perusteisiin vedoten.

Ehkä merkityksellisin traditio on nähdäkseni yhteisen rationaalisuuden ja sitä kautta rationaalisen keskustelun mahdollisuuksien perusteena. Tämä ei tarkoita monoliittista konsensusta, vaan mahdollisuutta löytää perusteita, jotka ovat sillä tavoin yhteisiksi tunnistettavia, että niihin voi vedota keskustelussa saavuttaen sitä kautta ehkä yhteistä ymmärrystä itse käsiteltävässä asiassakin.

Tässä käsitellyn pohjalta nykyistä tiede- ja yliopistokeskustelua hallitseva innovaatioiden haku voisi saada vastapainokseen ja vaihtoehdokseen vaalimisen rationaliteetin - ilman vähäisintäkään juhlapuheen omaisuutta tai nostalgiaa sen perusteissa (vrt. Suominen 2017a). Ehkä konkreettisimmin myös Kivistö ja Pihlström lähestyvät tätä kohdassa, jossa he kirjallisuuden tutkimuksen metodeista mainitsevat "ideahistoriallisen lähestymistavan" parhaiten ei-välineellistävän ideaalia lähestyväksi tuolla tutkimusalalla (s. 174).

\section{Sananen kirjastosta ja sen rationaliteetista}

Lopulta on paikallaan muutama sana Kivistön ja Pihlströmin kirjastoa akateemisen elämänmuodon ytimenä ja symbolina pohtivasta luvusta (s. 181-). Tekijöiden mukaan kirjasto esimerkiksi symbolisoi niin kuolevaisuudesta johtuvaa rajallisuuttamme - kun kukaan ei koskaan voi ammentaa kaikkea sitä, mitä kirjastossa on - kuin myös monitieteiseen tutkimukseenkin liittyvää ennakoimattomuutta, mihin liittyvä satunnaisen löytämisen mahdollisuudet. Kirjastonkin eksistentiaalinen ulottuvuus on esimerkiksi siinä, että kirjasto ylittää yksilön ajallista rajallisuutta (esim. s. 196-).

Kivistö ja Pihlström (s. 197) kirjoittavat myös, että " $[\mathrm{k}]$ irjasto ei koskaan vain katsele menneeseen, vaan päinvastoin myös menneen kautta tulevaan". Omasta puolestani ajattelisin, että luonteeltaan ehkä hieman funktionaalisessa sivistyk- sellisenkin elämän työnjaossa juuri kirjaston osa olisi katsella menneeseen toisten sitten ehkä katsellessa tulevaankin vaikkapa kirjaston tukemina. Tähän liittyen, kun olemisemme eksistentiaalinen aikarajallisuus tiivistyy Kivistöllä ja Pihlströmillä toistuvasti kuolevaisuuteemme, itse näkisin syntyneisyytemme ehkä vielä ratkaisevammaksi asiaksi. Kirjaston osa ja tehtävä on olla kuin peräseinä huoneessa, jonka vastakkaiselta seinältä avautuu ovia tulevaisuuteen ja sivuikkunoista näkee ehkä jotain nykytodellisuudesta (vrt. Suominen 2006).

Kirjasto voi tietenkin tarjota monenlaisia erityisempiä tuen muotoja. Suuri Opettaja kirjastossa on kuitenkin se, mitä kirjallisuus on jo tuottanut (scriptum est, Suominen 2016, 25-27), ja kirjaston perimmäisimmän rationaliteetin voisimmekin käsittää ensisijaisesti vastuuksi juuri siitä. Kirjastonhoitajuuden keskeistä maksimia ilmaisen scriptum est -velvoitteen käsitteellä (obligation of scriptum est. Emt., 52 ja 191). Tätä kautta myös kirjasto voitaisiin käsittää vaalimisen rationaliteetin puitteissa ja kirjaston ydintä olisivat kirjallisuus sekä väljästi tiedoksi kirjallisuudesta ymmärretty bibliografia.

\section{Lähteet}

Clarke, J.A. (1970) Gabriel Naudé 1600-1653. Hamden, Archon.

Gadamer, H.-G. (1992). Truth and method. New York, Crossroad.

Kivistö, S. \& Pihlström, S. (2018) Sivistyksen puolustus. Helsinki, Gaudeamus. (Viittaukset pelkin sivunumeroin).

Neuhouser, F. (2000) Foundations of Hegel's Social Theory: Cambridge: Harvard University Press.

Ricoeur, P. (1981). Hermeneutical function of distanciation. Teoksessa: Ricoeur: Hermeneutics and the human sciences. Cambridge University Press. Ss. 131144.

Suominen, V. (2006) Kirjasto on Peräseinä... ja paljon kaikkea, mitä on Peräseinän takana. Kirjastolehti 98(1):27. 
Suominen, V. (2016) About and on behalf of scriptum est..Oulu, Oulun yliopisto. http://jultika.oulu.fi/files/ isbn9789526212302.pdf (viitattu 28.4.2018)

Suominen, V. (2017a) Humanististen tieteiden omin käsitettävissäoleva rationaliteetti. Informaatiotutkimus 1(36). https://journal.fi/inf/article/view/63195/24666 (viitattu 28.4.2018).

Suominen, V. (2017b) No value-in-itself in About and on Behalf of Scriptum Est. Journal of Documentation. 73(6):1380-1386.

\section{Tietoa kirjoittajasta:}

Vesa Suominen, dosentti, Oulun yliopisto

vesa.suominen@oulu.fi 